DOI: $10.20472 /$ IAC.2018.044.015

\author{
STEPAN DZHUNDZHUZOV \\ Orenburg State Pedagogical University, Russian Federation
}

LARISA POLSHKOVA

Orenburg Theological Seminary, Russian Federation

\title{
THE USE OF THE MILITARY POTENTIAL OF BAPTIZED KALMYKS IN THE RUSSIAN ARMY AS A MANIFESTATION OF THE IMPERIAL POLICY OF ACCULTURATION (18TH - THE BEGINNING OF THE 20TH CENTURY)
}

\begin{abstract}
:
The settlement of baptized Kalmyks in the Middle Volga region, received the name Stavropol, was established in 1737. At the initiative of the first Orenburg governor Neplyuyev, it was transformed into an irregular army. The creation of the Kalmyk settlement took place in an environment where the Russian state fought decisively to establish its presence in the interfluve of the Volga and Yaik. Baptized Kalmyks significantly increased both the strength and the combat capability of Russian troops deployed in the Orenburg region. The first documented mention of the involvement of the Stavropol Kalmyks in military service dates back to 1739. As part of the government troops, they participated in punitive operations aimed at suppressing popular unrest in Bashkortostan. The military Cossack service became the main duty of baptized Kalmyks. Until 1815, it was expressed not only in the protection of state borders and the performance of police duties within the country but also in participating in wars with Prussia, Sweden, and Napoleonic France. Long-term interaction in combat conditions with Russian soldiers and Cossacks, a subordination of Kalmyk contingents to army officers exerted a strong accultural influence on the world view of the Kalmyks. However, later, in the conditions of the further modernization of the Russian army, the inefficiency of preserving the Stavropol Kalmyk regiment as a separate military unit became more evident for the authorities. In the 1830s, the commanders of the Orenburg Corps began to draw the government's attention to the unsatisfactory level of military training of Kalmyk servicemen, the lack of military education and combat experience among the command staff, and the lack of the Stavropol Kalmyk regiment. The noted shortcomings eventually gave rise to the disbandment of both the regiment itself and the entire Kalmyk army. After the annexation of the Stavropol Kalmyks to the Orenburg army, until 1917 they performed military service jointly and on common grounds with the Orenburg Cossacks. This was an important step in the development of the imperial policy of acculturation of baptized Kalmyks, aimed at their full "exposure". The research is executed the expense of a grant of the Russian Science Foundation (project No. 17-18-01008) in the Orenburg State Pedagogical University.
\end{abstract}

\section{Keywords:}

acculturation, Cossack army, Kalmyks, politics, Orenburg region

JEL Classification: F22, N90, N93 